\title{
空間の明るさ感の心理的決定要因 一光源の強さ感と空間の光量感—
}

\author{
正会員 石田泰一郎 (京都大学) 正会員 荻 内 康 雄 (京都大学) \\ Psychological Determinants of Brightness of a Space
- Perceived Strength of Light Source and Amount of Light in the Space-- \\ Member Taiichiro Ishida (Kyoto University) and \\ Member Yasuo Ogiuchi (Kyoto University)
}

\begin{abstract}
Which lighting attributes determine the brightness of a room space? We considered the perceived strength of the light source and the perceived amount of light in the space as potential determinants. We examined the relations between the actual brightness of the space and these two perceptions. In the first experiment, subjects evaluated the strength of the light source and the amount of light in the space using reference matching method. The results were consistent among the subjects, indicating they judged each of the two lighting attributes by some common criteria. In the second experiment, the brightness of the space, the strength of the light source, and the amount of light in the space of a model box were evaluated using the magnitude estimation method under various illumination conditions. We found that the brightness of the space was closely correlated with the perceived amount of light but not with the perceived strength of the light source. These results should prove useful in constructing a model for quantitatively estimating the brightness of a space.
\end{abstract}

KEYWORDS : brightness of a space, perception of lighting environment

\section{1. 緒言}

窒空間がどのくらい明るいと感じられるか, すなわち，空空間 の明るさ感は人が照明空間から感じとる主要な感覚のひとつであ ク，快適な照明空間を設計するために考虑すべき重要な要素とな る。これまでにも筀間の明るさ感に関卞る多くの研究 ${ }^{1101}$ が行わ れており, 大別して空間内の輝度分布に関する物理量と光源の輝 度に関する物理量が, 空間の明るさ感に影響する要因として見い だされている．ただし，これらの要因の空閒の明るさ感に対する 影響は, 個別には明らかにされているものの, 様々な公空間や照 明方式に幅広く対㣽た空間の明るさ感の一般的な評価手法の開 発には至っていないのが現状である。

ところで, そもそも空間の明るさ感とは光のどのような特徵を 捉之た感覚なのだろうか. 例えば，ある面の明るさの評価を考之 てみる，面の明るさとは，それを具体的に記述すれば，その面か ら発せられる光の量の大小に関わる感覚である。したがって，そ の評価にはその面から発せられる光の量を表す輝度を基準にすれ

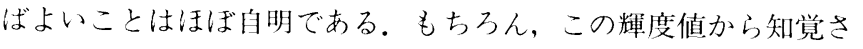
れる明るさを推定亦るためには, 輝度と明るさの非線形性, 色の

*本論文の一部は1999年 CIE 大会において発表した。また，平成11年度照明学会全国大 会で荻内康雄が講演した。
効果, 周辺部との相互作用, 眼の順忍などの多くの要因を考虑亦 る必要があり容易ではない。しかし，少なくとも面の輝度が評価 の基準となる物理量であることは確かである。一方，空間の明る さ感は，それが空間内の光に関するどのような物理的特徵を捉之 た感覚であるのかということも必ずしも明らかではない。この点 に関して成定 ${ }^{11)}$ は人間がある部屋で感ずる「明るさの感じ」には 種々のものがある。一つは「強い光で照明されているな」という 明るさの感じであり，他の一つは，「明るい色の内装で仕上げられ

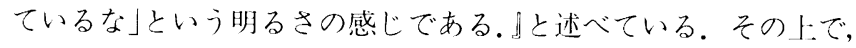
前者こそが照明環境の明るさに最も近い印象であるとの解釈を示 している。池田ら ${ }^{1213)}$ は人間が照明された空間を見たときに瞬時 に形成される光の状況に関する認識を照明認識視空間と名付け た。そして，䇪の中に感じられる照明光の強さを空間の明るさ感 に対忘与る認識量として，照明認識視空間の大きさと表現してい る.また, 岩井ら ${ }^{9)}$ は, 照明印象と呼ばれる光の強さの認識を卆間 の明るさ感と関連する心理量としてとりあげ,「部屋空閒の明るさ 感は，この照明印象の影響を強く受け，その知覚量が大きいほど 明るさ感は高くなる」という仮説を提案している。これらの考之 方をまとめると, 窒空間の明るさ感とはその空間に対する照明の 強さに対する感覚であり，人がその照明の強さをどのように認識 するかによって明るさ感は決定されるとなるだろう。

ただし, 空間の明るさ感評価のベースとなる物理量を算定する 
ためには，照明の強さに対する感覚の意味寸るところをさらに具 体的に記述する必要があると思われる。そこで，本研究では空間 の照明状沅の認識に関わる基本的な要素として 2 通りの感覚を考 之る。一つ洸光源から発する光の量に対する感覚であり, これを 光源の強さ感と呼ぶことにする。もう一つは，空間内に満ちてい る光の星に対する感覚であり，これを空閒の光量感と呼ぶことに する。すなわち，㛎る空空間に対して光源からどのくらい強い光 が照射されているかという感覚と，その光が窒内にどのくらい行 き渡り，空閒を満たしているかという感觉を区別して考之る。光 源からの直射光と室全体にわたる拡散性の光の相対関係が, 空間 の明るさ感に影響することは著考らの過去の研究8で毛示唆され ており，この2つの感觉を基礎にして空間の明るさ感の心理的な 決定過程を検讨寸る意義は高いと思われる。ここで, これらの感

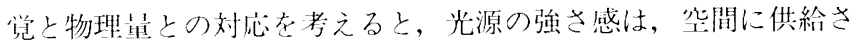
れている值射光の量に対応寸るであろう。一方，空閒の光量感が どのような物理昌と対㐫するのか自明ではないが，通常の室内を

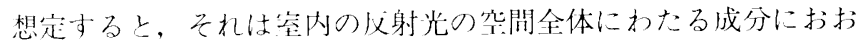
上そ対忠すると思われる。䈍間の明るさ感が，この2つの感覚と どの上うな関係にあるのか明らかになれば，その評価のために算 出すべき物理最も明確になってくる。そこで本研究では，照明空 閒に扮ける光源の強さ感と究間の光量感に着目し, 空間の明るさ 感がこれらの光の恋識とどのように関係するのか明らかにするこ と老目的とする。実験 1 では，まず被験者が光源の強さ感と空間 の光星感を個別に判断寸ることができるかどうか調べる，次いで 实験 2 ではそれらの光の認識量と空間の明るさ感の関係を娭討多 万。

\section{2. 実験 1 ：光源の強さ感と空間の光量感の評価}

\section{1 実験方法}

実験 1 では被験者が光源の強さ感と空䦭の光量感を独立に判断 できるかどうか調べた。実験はテストボックスと参照ボックスと 名付けた模型堭を用いて行った。被験者はテストボックスと参照 ボックス内交交にに観察し，テストボックス内の光源の強さある いは究間の光氧と，参照ボックス内の光源の強さあるいは空間の 光晶がそれぞれ等しく感じられるように，参照ボックスの光源の 料度を調節する。参照ボックスは光源の強さ感と空間の光量感の 詊価のために，それぞれ別のものを用意した，光源の強さ感の評 洒に用いる参照ボックス（参照ボックス $($ 黑)）は，指向性のある 光源によって照明され，内壁が黑で蒤装されている，そのため内 部での反射光は少なく，ボックス内の光の大部分は光源からの直 射光となり，光源の強さの判断が容易なように考虑されている. 空間の光量感の評価に用いる参照ボックス（参照ボックス（白）） は, 拡散性の光源によって照明され, 内壁が白で叙装されている。 そのため, 内部の光の多くは壁面・床面での反射による搪散光と なり, 空間にほぼ一様な光が満ちている状態になり, 空間の光量 感の判断が容易になるように意図した。

\section{2 実験条件}

テストボックスと参照ボックスの概略を図 1 に示寸。光源の強 さ感と空間の光量感のマッチングに用いられた参照ボックスはと もに木製のもので，大きさは幅 $0.30 \mathrm{~m} \times$ 奥行き $0.45 \mathrm{~m} \times$ 高さ 0.45 $\mathrm{m}$ である。ボックス正面には幅 $0.30 \mathrm{~m} \times$ 高さ $0.20 \mathrm{~m}$ の開口部があ り，被験者はこの開口部から参照ボックス内部を観察する。ボッ クス泟面の上部（四の斜線部）は，木製の板で被われており，被 験者からは照明器具や搪散板などは見ることができない。床面に

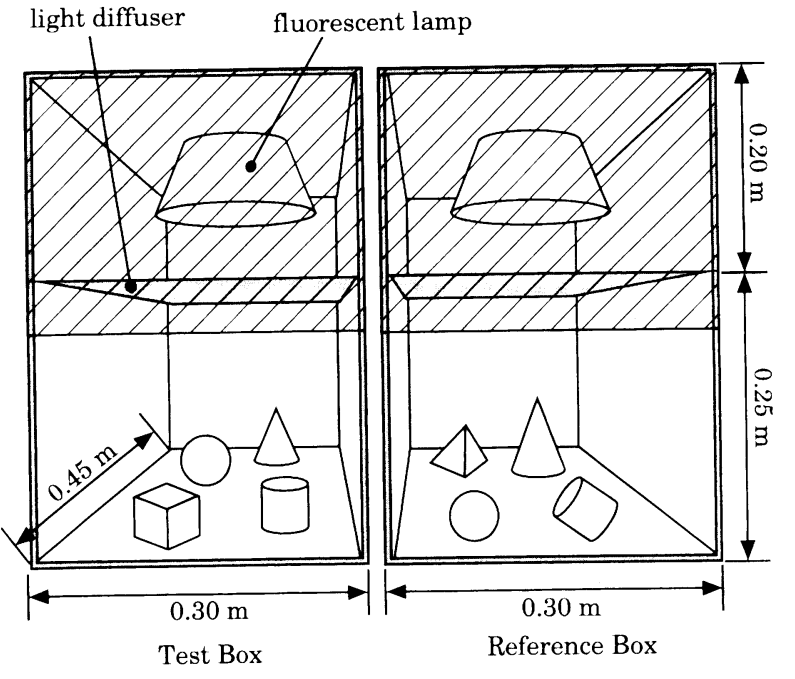

図 1 実験 1 のテストボックスと参照ボックスの概略図 左：テストボックス, 右：参照ボックス（白）

Fig.1 Illustration of the test box (left) and reference box (W) (right) used in experiment 1 .

は3 種類の明度（反射率：2.6\%，17\%，38\%)の無彩色で塗装さ れた 4 種の立体を盅いた。立体の形状は，球，円錐，以柱，立厅 体，四角錐であり，招㧍よそ図1に示文ように配置されている。 これらの立体の面の明るさや㓌影によって, 被験者が参照ボック ス内部の光の強さや向きなどを判断するための存効な手がかりを 得ることを意四した。ただし，雨ボックス間で，形状と反射率が 等しい同一の立体は存在しない。

参照ボックス（黑）の内部はつや消しの黑い塗料（反射率：4.1 \%)で涂装されている，光源は八ロゲンランプであり，指向性の 光で参照ボックス内を照らしている。またデイライトフィルター を使用することで，照明光の色温度は6500K となっている，床面 照度はほぼ均一で，光源は被験者の視野には入らない。照明の強 度の調節はライトコントローラーを用いて被験者が行う。参照ボ ックス（问）の内部はつや消しの白い塗料（反射率：82\%）で染 装されている。また，天井部に取り付けられたコンパクトタイプ の蛍光灯の下部（床からの高さ $0.25 \mathrm{~m}$ ）に白色のアクリル板が取 り付けられており，ボックス内を照らす光は拡散性が高くなる。 内部の照度分布はほぼ均一である。照明器具およびアクリル板は 被験者の視野には入らない。照明の強度の調節は, 光源の強さ感 のマッチングの際と同様に，ライトコントローラーを用いて被験 者が行う。照度レベルが低い条件の際には，中性フィルターを照 明器具に取り付けて減光した。

テストボックスも木材で製作した模型であり，その大きさは参 照ボックスと同一である。テストボックスは内部の反射率が $42 \%$

$(\mathrm{Box} \mathrm{H}), 27 \%(\operatorname{Box} \mathrm{M}), 13 \%(\mathrm{Box} L)$ の 3 種類がある。さ らに実験条件として床面中央の水平面照度が10，30，100，300, $1000 \mathrm{~lx}$ の 5 段階を設定した。テストボックスの床面にも, 参照ボ ックスと同様に，被験者の照明状況の判断の手がかりを与えるた めに，3段階の明度の無彩色で塗装された 4 つの立体を置いた。 テストボックスには, 床から $0.25 \mathrm{~m}$ の高さに白色アクリル板が取 り付けられており，このアクリル板を通してコンパクトタイプの 蛍光灯がテストボックス内部を照明している. 内部の照度分布は ほぼ均一であり，照明器具㧍よびアクリル板は被騟者の視野には 
入らない.テストボックス内の照明の強度はライトコントローラ 一を用いて実験者が調節方る。照度レベルが300 lx 以下の時には, 中性フィルターを照明器具に取り付けて減光している.

\section{3 実験手順}

実験で被験者に与えたインストラクションは，光源の強さ感の 評価の場合は,「テストボックスの光源の強さと参照ボックスの光 源の強さが等しく感じられるように，参照ボックスの照明を調整 して下さい.」という内容であり, 空間の光量感の評価の場合には, 「テストボックス内に満ちている光の量と参照ボックス内に満ち ている光の量が等しく感じられるように，参照ボックスの照明を 調整して下さい.」という内谷である。被験者が評価した光源の明 るさ感, 空閒の光量感とは, これらの教示に基づいて被験者各自 が判断したものであり，これらの教示以外に評価に際して着目す べき物理的特徵などの具体的な指示は与えていない。

被験者はテストボックスと参照ボックス内を交百に観察し，丽 ボックス内の光源の強さ感あるいは空間の光量感が等しく感じら れるように参照ボックスの光源の輝度を調節する。調整に要する 時閒に制限はなく，ボックスの観察も白由に行ってよい.ただし， 離れた位置から両ボックスを同時に観察すること，頭を下げて開 口から光源面を直接見ることは禁止した。

1 回のセッションにおいては，光源の強さ感，あるいは空間の 光量感のいずれかのマッチングが行われる。また，テストボック 又は内壁の反射率の条件 $(\mathrm{L}, \mathrm{M}, \mathrm{H})$ のいずれか一..つが選択され， 5 段階の照度条件について各 5 回の試行が行われる。このよjな 実験セッションを, 光源の強さ感, 空間の光量感の 2 通りの評価 項目とテストボックスの 3 種類の内装反射率による 6 通りの組み 合わせについて 2 回ずつ行った。したがって, 被験者 1 人当たり 計12回のセッションを行い, 各条件について10回のマッチングの 結果を得た.

被験者は著者らの研究窒の学生及び教官である。実験に参加し
た著者 1 名を除いて，被験者には実験目的の詳細は知らされてい ない，光源の強さ感の評価尖験を行った被験者は 5 名，空閒の光 量感の評価実験に参加した被験者は4名であった。

\section{4 結果}

図 2 に実験 1 の被験者平均の結果を示寸。困 $2($ a) はテストボッ クスと参照ボックス (黒)の光源の強さ感のマッチングが成立し た照度の対数值を示し，罒 2 (b)はテストボックスと参照ボックス （白）の空間の光量感のマッチングが成立した照度の対数值を示 している。 3 種のシンボルはテストボックスの反射率条件に対応

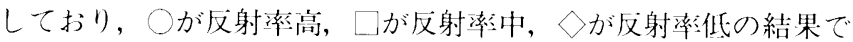
ある。䛊差棒は被験者間の標準偏差であり，四の混乱を避けるた め各シンボルの片側のみ表示してある。また直線は最小日乗法に よる问帰伯線を示している。四に示された結果より，テストボッ クスと参照ボックスの光源の強さ感，あるいは瑩間の光量感が等 しく感じられた両ボックスの照度は，対数軸上でほぼ直線をなす 一定の関係が成立し，また被験者間の結果の将らつきも少ない。 この結果より, 被験者は光源の強さ感と空間の光量感の大小を, 何らかの光の特徵の知覚に基づいて判断可能だったことが示唆さ れる。各被験考毎の結果も，罒 2 に示した平均の結果とほぼ闰様 の傾向を示しており，被験者内の試行毎のばらつきは被験者間の 平均のばらつきと同程度ないしそれ以下であった。したがって光 源の強さ感と空閒の光量感の判断注被験者内抽よび被験者間に抽 いて一貫しており，被験者は何らかの其通した光の状沉判断に基 づいてマッチングを行っていたと考えてよいだろう。

先に光源の強さ感は物理的に淔射光の量に対忍し，空間の光 量感は空間全体にわたる拡散的な光の量に対応するとの推測を述 べたが，㿤験 1 の結果からは，このことは必ずしも明らかではな い．ただし，テストボックスの内部の反射率が高く(すなわち直 接照度の成分が少なく) なるほど，光源の強さ感は高くなってお り，本尖験において被騃者が判断した光源の強さ感が，物理的な (a) Strength of light source

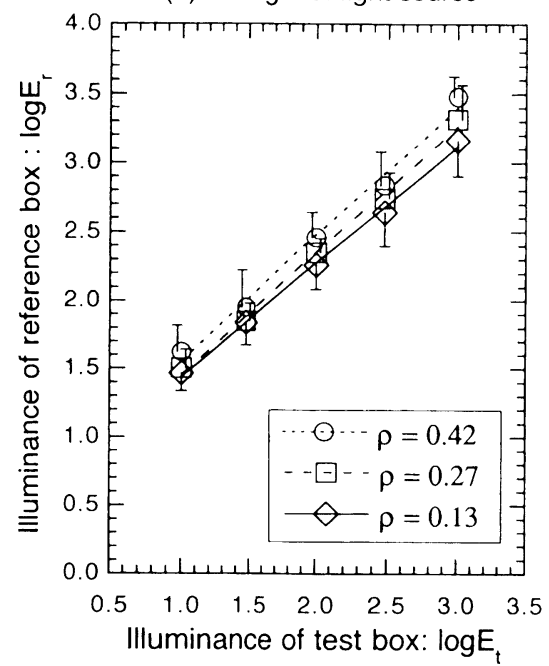

(b) Amount of light in the space

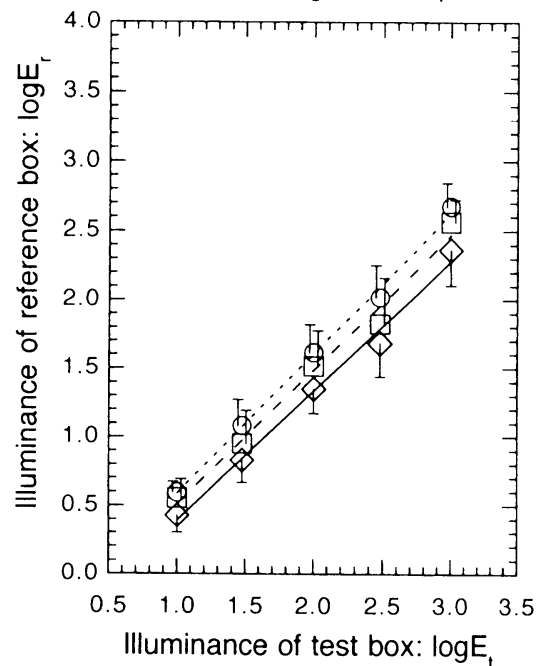

図 2 実験 1 の結果

(a)光源の強さ感のマッチング，(b)空間の光量感のマッチングが成立したときのテストボックスの照度 の対数值を，参㬎ボックスの照度の対数值に对してプロットしたもの．5名の被検者の平均．誤差棒 は被験者間の標準偏差.

Fig.2 The results of experiment 1.

Logarithm of illuminance of the reference box are plotted against logarithm of illuminance of the test box when the strength of the light source (a) or the amount of light filled in the space (b) were matched. The results are averaged over five subjects. Error bars show the standard deviation of the subjects. 
直射光の量をそのまま反映したものではないことは明らかであ る.

実験 1 の結果で確認しておくことは, 被験者は光源の強さ感, 空間の光量感を光の何らかの特徵によって評価することができ, その評価は被験者内, 被験者間で一貫していたということである.

\section{3. 実験 2 : 空間の明るさ感と光源の強さ感，空間の 光量感の相互関係}

\section{1 実験概要}

空間の明るさ感とは，より具体的な記述で置き換えれば，どの くらい強い光源で照らされているかという感覚なのか, どのくら い多くの光が空間を満たしているかという感覚なのか，あるいは それらの感覚が複合された結果生じる感覚なのであろうか. 実験 2 では, 空間の明るさ感という感覚が光源の強さ感, 空間の光量 感という感覚とどのような関係にあるのかということについて検 討する。

実験の方法は数種のテスト空間に対して空間の明るさ感, 光源 の強さ感, 空間の光量感のそれぞれをマグニチュード評価法によ り評価し，それらの相関を調べた。被験者のタスクは，テストボ ックス内部の光源の強さ感, 空間の光量感, 空間の明るさ感を基 準ボックス内部のそれらを100として，それぞれ数字で評価するこ とである。

\section{2 実験条件}

テストボックスと基準ボックスは木製の箱であり, 大きさはと もに幅 $0.30 \mathrm{~m}$, 奥行き $0.45 \mathrm{~m}$, 高さ $0.45 \mathrm{~m}$ である. 被験者に面し たボックス正面には, 幅 $0.30 \mathrm{~m}$, 高さ $0.20 \mathrm{~m}$ の開口部があり, 被 験者はここから内部老観察する，床面には被験者が内部の照明状 況を把握する手がかりになるように，3 種の明度(反射率：75\%， 58\%，27\%）のいずれかによって塗装された無彩色の立体が 4 個 置かれている。これらは，実験 1 の場合と同様に，被験者にボッ クス内の照明状況の判断の手がかりを与えることを意図したもの である．立体が置かれたテストボックスと基準ボックス内の様子 を撮影した写真を図 3 に示す。ただし，被験者が両ボックスを同 時に観察することは禁止してあり，実際には被験者はこれらのボ ックスを交互に観察した。

テストボックスは図 4 に示す 4 通りの照明パターンによって内 部を照らすことができるように制作した．図４はテストボックス の側面からの概略図であり，被験者は図の右側からテストボック ス内部の空間を観察することになる。まず，テストボックスの天 井面中央には, メイン光源のコンパクトタイプ蛍光灯, 天井面の 最奥部には補助光源のミ二蛍光灯 (6 W) がそれぞれ取り付けら れている。また床面から $0.25 \mathrm{~m}$ の高さには拡散板としてアクリル 板，あるいは配光制御のためのルーバーを取り付けることができ
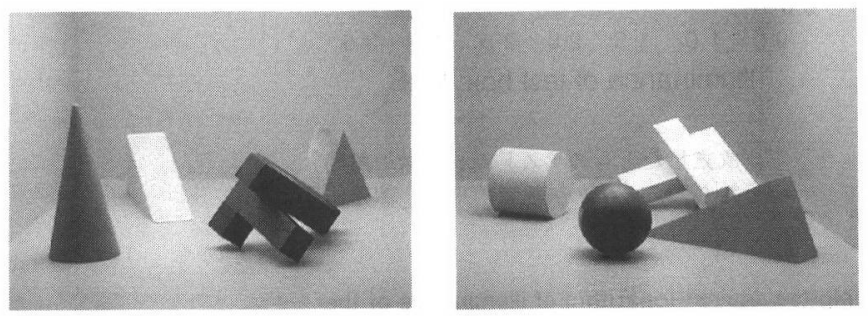

図 3 実験 2 のテストボックス（左）と基準ボックス（右）の写真

Fig.3 A photograph of the test box (left) and the standard box (right) used in the experiment 2 .

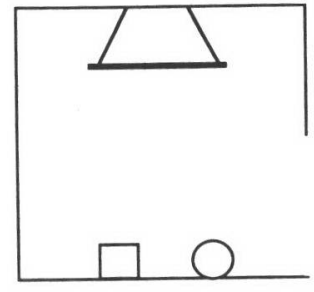

(a) Direct: $\mathrm{Dr}$

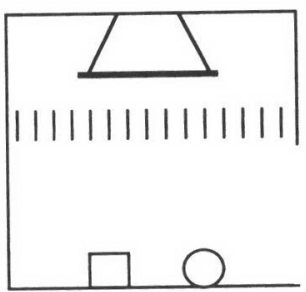

(c) Louver: Lv

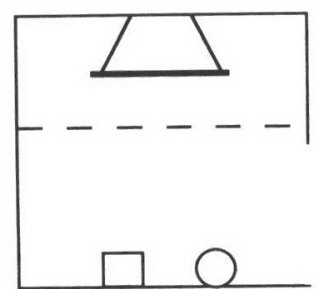

(b) Diffusing: Df

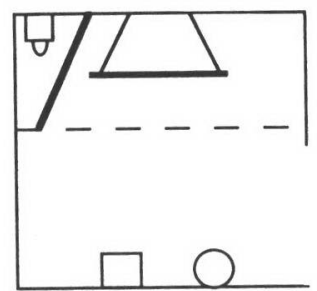

(d) Wall lighting: Wl
図 4 実験 2 のテストボックスの 4 種類の照明条件の概略図

Fig.4 Illustration of four lighting conditions of the test box used in experiment 2.

る.この照明ユニットを切り替えることで 4 通りの配光が実現さ れる。さらに，壁と床の全面が，高，中，低の反射率 $(42 \% ， 27$ \%，13\%）の無彩色で塗装された 3 種の室ユニットを作成した. 4 通りの照明ユニットと 3 種の室ユニットを組み合わせることに よって, テストボックスの条件は計 12 通りとなる.

具体的に 4 通りの配光パターンを説明する. 照明条件 $\operatorname{Dr}$ (直接 照明）では，拡散板，ルーバーは用いずに，上面に取り付けたメ インの蛍光灯のみで内部を直接照明した。被験者には光源直下の 部分が強く照らされているのが分かり, 床面照度は不均一となる。 照明条件 Df (拡散照明) では, 白色アクリル板を通してメインの 蛍光灯のみで照明した。 そのため内部の光は拡散性が高くなり, 照度の均一性も高い. 照明条件 LV (ルーバー) では, ルーバーを 取り付け, メインの蛍光灯のみで照明した。この条件ではルーバ 一によって光源からの横方向への配光が制限されるため, 照明条 件 Dr と比べて特に空間内の鉛直面照度は低くなる. 照明条件 W1 (ウォールライティング) では，アクリル板を通して内部を照明 する拡散照明に加えて補助光源によって奥の壁のみを照明するウ オールライティングを付け加えた. 実験では, すべての照明条件, 反射率条件の組み合わせにおいて, 床面中央での水平面照度を 100 $\mathrm{lx}$ に統一した。いずれの条件においても照明器具やアクリル板な どは被験者の視野に入らない。

基準ボックスはテストボックスと同一の大きさをもち，内部の 反射率は $66 \%$ で，どのテストボックスよりも高い反射率をもつ.

上面にはコンパクトタイプ蛍光灯が取り付けられていて, 床面か

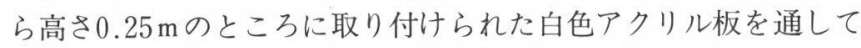
照明される。すなわち，照明条件はテストボックスの照明条件 Df と同様であり，内部はほぼ拡散照明になっている。基準ボックス についても床面中央での水平面照度は $100 \mathrm{~lx}$ である. 基準ボック スについても, 照明器具やアクリル板は被験者の視野に入らない.

\section{3 実験手順}

実験実施にあたって被験者には以下のようなインストラクショ ンが与えられた.「基準ボックスの内部空間に感じられる『光源の 強さ』, 『空間に満ちている光の量』、『空間の明るさ感』のそれぞ 
れを100としたとき，テストボックスの『光源の強さ』，『空間に満 ちている光の量』、『筀閒の明るさ感』がそれぞれいくらであると 感じられるか数字で評価して下さい.」

被験者は，実験 1 と同様に，テストボックスと基準ボックス内 を交互に観察し,テストボックスの光源の強さ感, 空間の光量感, 空間の明るさ感を, 基準ボックスのそれらを 100 とて数值で回答 する。1回のセッションにおいては，テストボックスのある1つ の反射率の窒ユニットを選択し，それに対して4 通りの照明条件 それぞれについて各 2 回の評価を行った。このような奏験セッシ ヨンを，3通りの仿射率に対して 2 回ずつ，計 6 セッション行う ことによって, 被験者 1 人当たり各条件について 4 回の評価の結 果を得た。

被験者は実験 1 に参加した著者らの研究公の学生及び教官の4 名である。

\section{4 結果}

図 5 は央験 2 の被験者平均の結果を, 照明条件別にプロットし
たものである．各グラフの横軸はテストボックス内部の反射率で あり，それぞれの条件で基準ボックスを基準として評価された光 源の強さ感 $(\bigcirc)$, 架閒の光量感 $(\square)$, 空間の明るさ感 $(\boldsymbol{\Delta})$ を 縦軸にとってある． 3 種の感覚の変化の傾向を比較すると，空間 の光量感と空閒の明るさ感は，古べての照明条件において，テス トボックスの反射率の増加に伴って大きくなっている，それに対 して光源の強さ感は，テストボックスの反射率が $13 \%$ から $27 \%$ に 移行するところで低下しており，他の2つの感覚とは明らかに異 なった傾问を示している。テストボックス内部の照明が拡散性で ある条件 Df と W1に比べて, 照度分布あるいは配光に不均一性が ある条件 Drと Lvにおいて, 光源の強さ感と空間の光量感の閒の 違いは顕著である。また，テストボックス内の反射率が低い条件 ほど洏感覚の隔たりは大きくなっている。これらの結果は光源の 強さ感と空閒の光量感が基本的に独立した感覚であることを示し ている。

図 6 は空間の明るさ感と光源の強さ感, 空間の光量感の関係を
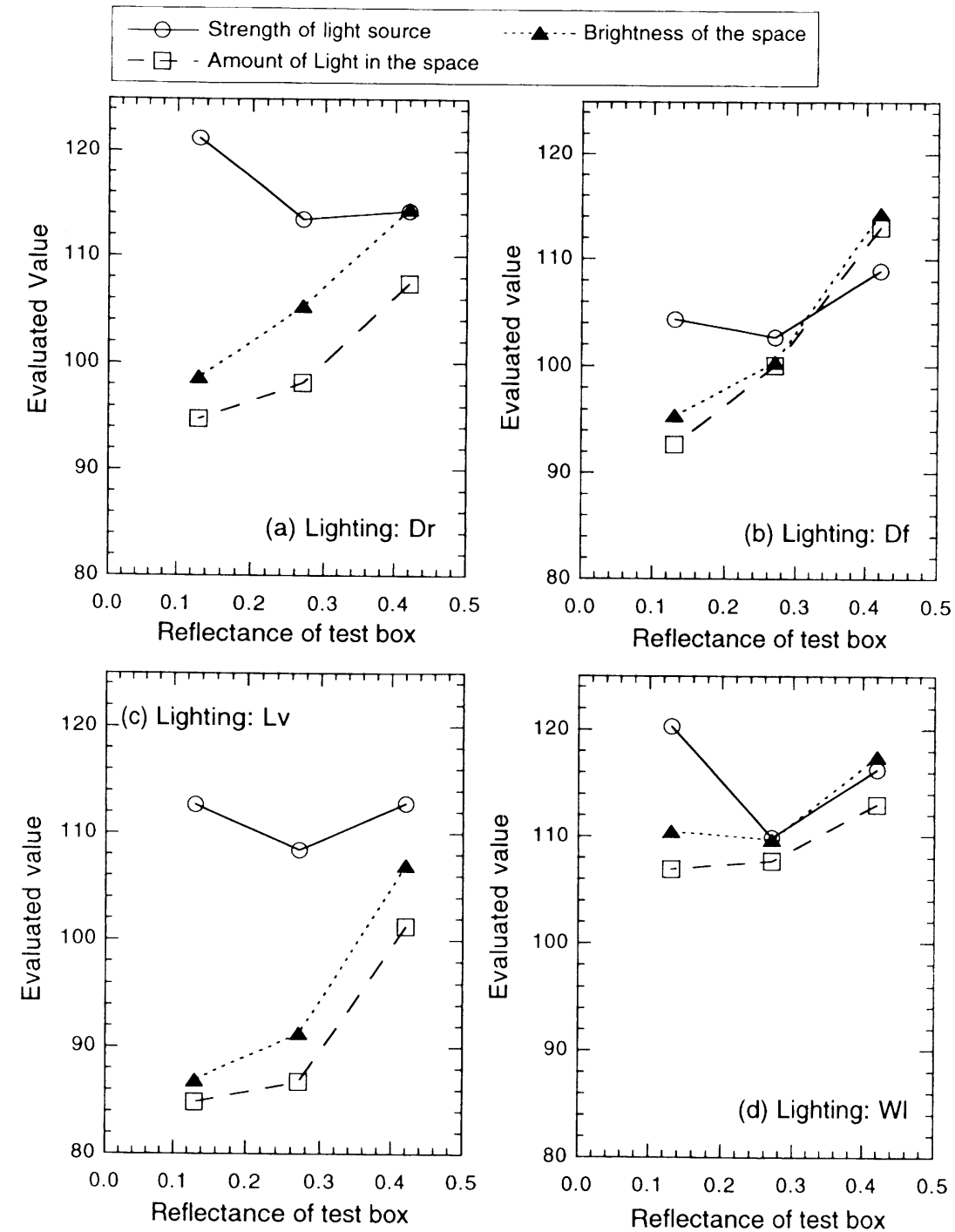

図 5 実験 2 の結果：照明条件別

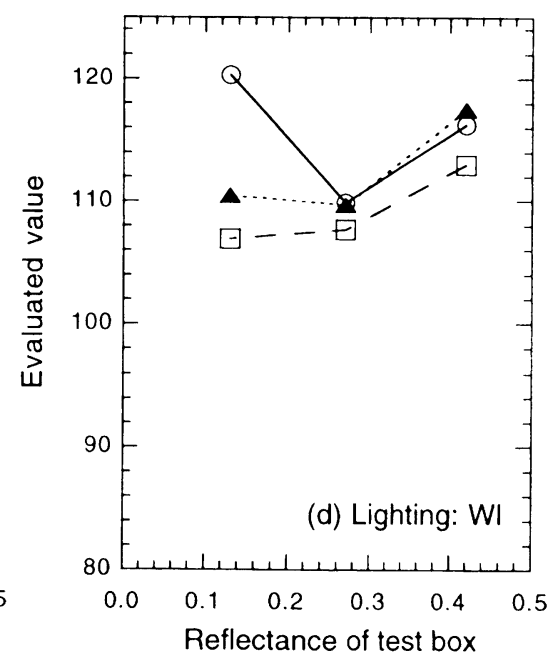

4 つの照明条件別に光源の強さ感 $(\bigcirc)$, 空間の光量感 $(\square)$, 空間の明るさ感

トボックスの反射率に対してプロットしてある。

Fig.5 The results of experiment 2 for each of four lighting conditions.

Evaluated values for the strength of the light source $(\bigcirc)$, the amount of light filled in the space

$(\square)$, and the brightness of the space $(\boldsymbol{\Delta})$ are plotted against reflectance of the test box. 

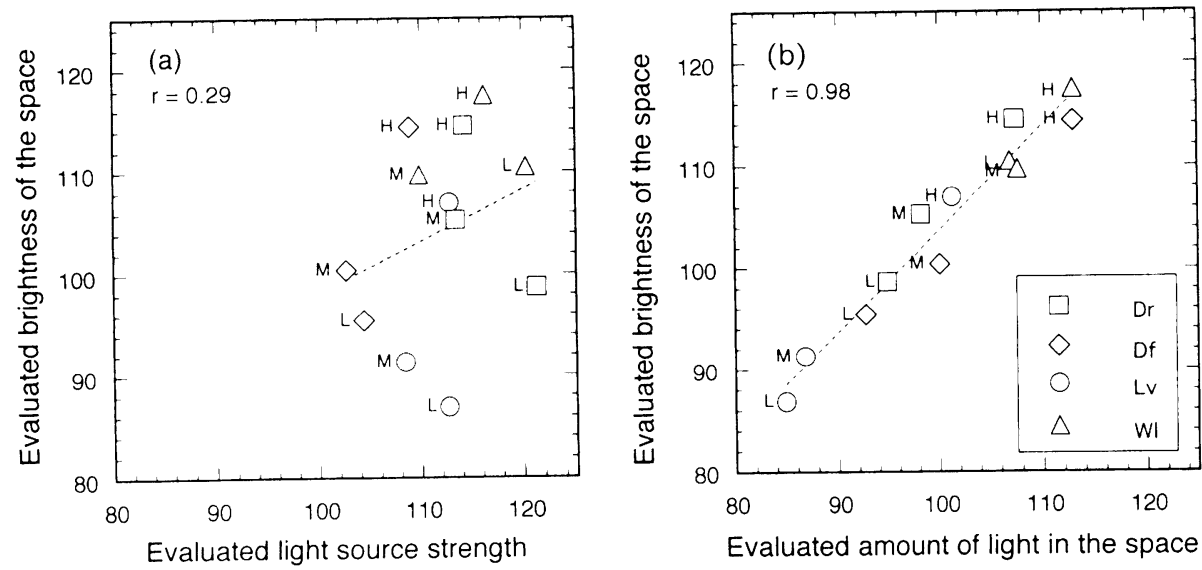

図 6 実験 2 の結果：まとめ

䒠験 2 の全ての条件の絬果を公わせてプロットしたグラフ。(a)光源の強さ感と空間の明るさ感，(b)空 間の光曼と感と䦌の明るさ感の相関関係走示与.

Fig.6 The results of experiment $2:$ summary.

The results of all conditions in experiment 2 are plotted together. Evaluated brightness of the space is plotted as (a) perceived strength of the light source, or (b) perceived amount of light filled in the space.

分かりや守く表示するため，それぞれの感覚の評価值を相互にプ ロットしたものである。条件による傾问の有無を見るため，照明 条件の違いをシンボルによって区別し，テストボックスの反射率 を H (42\%)，M (27\%)，L (13\%)の記号で示してある。ただし， 相関係数 $r$ は全デー夕を対象として計算したものである。この困 より空間の明るさ感仕空間の光量感，才なわち染間に満ちている と感じられた光の量に強く相関していることが明らかである。一 方, 光源の強さ感と空間の明るさ感の間には相関がみられない. 実験 2 の結果から空間の明るさ感に相関する主要な感覚は空間の 光最感であると結論づけることができる。

\section{4. 考察}

本研究の結果は, 光源が強いという感覚と空間に光が満ちてい るという感覚は区別することが叮能であり, 空間の明るさ感に相 当するの注，直接的には後者の感覚であることを意味している。 光源の強さ感は，少なくとも今回の実験条件においては，架間の 明るさ感を決定づける第一の要因ではない。したがって, 例えば, 光源からの直接光が強くても, 公内の文射率總低い場合には, 内 面で反射して空間を満なす光が少なくなるので，その空間は明る くは感じられないことになる。このように，光源の強さ感が空間 の光量感と相関しない照明状涊においては，空間の明るさ感と光 源の強さは解離する。明るいと感じられる等開を実現するために は, 光源が強いだけでは不卜分であり, 強い光源によって照明さ れた明るい反射而（女るいは拡散性の発光面）の存在によって， 空閣に光が十分満ちているという感觉を提供することが必要とい える，ただし，通常の窒内環境であれば，比較的高い内装反射率 になっていることが普通であり，そこでは光源の強さと空間の光 是は物理的にも相関子ることになる。このことは，これらの光の 成分が，照明環境の心理評価に扔いて，あまり積極的に区別され てこなかった理由のひとつだろう。実際の照明空間では，照明の 強さ感と空間の光量感のバランスによって多様な効果や印象が引 き出される. 照明の強さ感と空間の光量感という感覚を区別して 考えることは，照明環境の研究のみならず，現実の照明設計にお いても有益であると思われる。
本研究においては，空間の明るさ感が空間の光量感と高い相関 を示すことが明らかになったが, 室内の内装表而が光沢をもつよ うな場合や，視野に入る光源に輝きが女るような場合4110)などに おいて, 光源の強さ感が空間の明るさ感に与える影響については 未解明である。

最後に，今回の奏験では比較的単純な物体が置かれた模型ボッ クスを用いたが, 被娩者はボックス内の光の状況を，お招むね的 確に把握できたものと思われる。これは奏験条件に忘して一貫し た結果が得られたことからも推察できる。ただし，被験者の一部 から，もう少し豊富な対象物があれば，光の状況はより分かりや すくなるだろうとの指摘もなされた。照明の認識には多様で微妙 な要因が影響することを考えると，より現垁に近い状況での研究 も必要になる。

\section{5. 結語}

本研究では，空閒の明るさ感が具体的にどのような光の成分を 捉之た感覚であるのか検封するため, 光源の強さ感と空間の光量 感に着目し，それらと空間の明るさ感の関係を娭討した。実験1で は, 光源の強さ感と空間の光量感の判断が被験者内, 被験者間で 一共しており，被騃者は何らかの手がかりに基づいて，これらの 光の成分を把握できることが示された。奏験 2 より, 空間の明る さ感は空間の光量感に対して高い相関を示し，照明の強さ感とは 相関しないことが明らかになった。この結果は，空間の明るさ感 とは，基本的には，空閪に満ちている光の量に対する感覚である ことを意味している。ささらに,この結果は, 空間の明るさ感の評 価モデルを構築するためには, 光源の強さ感に対芯する物理量で はなく，空間に満ちていると人が認識する光の量に相関する物理 量を算定することが必要になることを示している.ただし，照明 環境の状況によっては, 照明の強さ感が空閒の明るさ感の形成に 大きな役割を果たす可能性は否定できず，空間の明るさ感を決定 づける心理過程については，さらに検討を要亦る。

本研究の一部は平成11年度照明学会研究・教育助成金奨励研究 によって行われた。 


\section{参 考 文 献}

(1) Bellchambers, H. E. : Illumination, colour rendering and visual clarity, Light. Res. Technol., 4-2, pp.104-106 (1972).

(2) Bernecker, Craing A. and Mier, John M. : The effect of source luminance on the perception of environment brightness, J. Illum. Engng. Soc., Fall-, pp.253-271 (1985).

(3) Loe, D. L., Mansfield, K.P. and Rowlands, E : Appearance of lit environment and its relevance in lighting design : Experimental study, Light. Res. Technol., 26-3, pp.119-133 (1994).

(4) Akashi, Y., Akashi, I., Tanabe, Y. and Kanaya, S. : The sperkle effect of luminaires on the sensation of brightness, Proc. 23th CIE, 1, pp.176-179 (1995).

(5) Tiller, D.K. and Veitch, J. A. : Perceived room brightness : Pilot study on the effect of luminance distribution, Light. Res. Technol., 27-2, pp.93-101 (1995).

（6）小林茂雄, 中村芳樹, 木津努, 乾正雄 : 空間の輝度分布が 室内の明るさ感に与之る影響, 建学計論, 487, pp.3341 (1996).

(7) Ogiuchi, Y., Ishida, T. and Hokoi, S. : Quantitative estimation of environmental brightness based on its perceptual composition, Proc. 24th CIE, 1-1, pp.92-96 (1999).

（8）石田泰一郎, 荻内康雄 : 参照マッチング法による空間の明 るさ感評価の基礎的検討, 照学誌, 83-5, pp.295-305(1999).

(9) 岩井彌, 齋藤良徳, 墨貞宏, 阪口敏彦: 住宅居間の明るさ 感一ダウンライトを設置した場合一, 照学誌, 83-2, pp.81 -86 (1999).

(10) 明石行生, 向健二, 坂上美香, 田辺吉徳：省エネルギーと 快適性の両立を目指したオフィス照明システムーパーソナ
ル\&アンビエント照明方式の実用化一, National Tech. Rep., 43-2, pp.200-206 (1997).

(11) 成定康平：明るさ感...ある複雑な感じ, 照学誌, 67-7, pp. 297-299 (1983).

(12) 池田光男, 金子文香 : 照明認識視空間への初期視覚情報の 影響一明度と彩度の場合一, 照学誌, 80-5, pp.319324 (1996).

(13) 池田光男, 本永景子, 松澤伸子, 石田泰一郎：色パ夕ーン の照明認識視空間と局所照明認識閾, 光学, $22-5$, pp.289298 (1993).

（受付日1999年11月 8 日／採録日2000年 4 月 13 日）

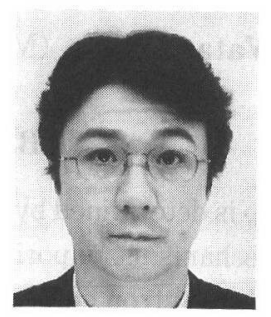

$$
\text { 石田 泰一郎 (正会員) }
$$

京都大学大学院工学研究科生活空間学専攻

昭和 37 年 9 月 11 日生まれ。昭和 61 年東京工 業大学理学部卒業, 平成 3 年東京工業大学大 学院物理情報工学専攻博士課程修了. 工学博 士. 現在, 京都大学大学院工学研究科助教授. 専門は建築視環境, 照明, 色彩, 視覚心理物理学. 日本建築学会, 日本色彩学会, 日 本光学会, 日本照明委員会, 日本視覚学会, OSA 各会員.

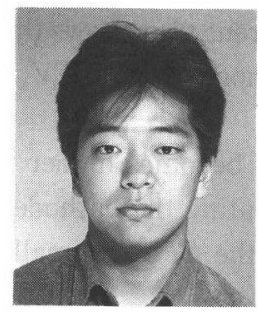

\section{荻内 康雄 (正会員)}

京都大学大学院工学研究科

昭和 49 年 11 月 5 日生まれ。平成 9 年 3 月京 都大学工学部建築学科卒業, 平成11年 3 月京 都大学大学院工学研究科生活空間学専攻修士 課程修了. 現在同博士課程在学中. 照明学会, 日本建築学会, 日 本照明委員会会員. 